\title{
Research
}

\section{Synergies, Trade-offs, and Losses of Ecosystem Services in Urban Regions: an Integrated Multiscale Framework Applied to the Leipzig- Halle Region, Germany}

\author{
Dagmar Haase $^{1}, \underline{\text { Nina Schwarz }}^{2}, \underline{\text { Michael Strohbach }}^{3}$, Franziska Kroll $^{4}$, and Ralf Seppelt $^{2}$
}

\begin{abstract}
Because we have entered the 'millennium of the cities', urban ecological research needs to account for the provisions ecosystem services provide to urban regions. In urban areas, ecosystem service assessment studies need to account for the complex land use patterns, which change over relatively short periods of time. We discuss an analytical framework for the spatial and temporal integration of different ecosystem services in an urban region to determine synergies, trade-offs and losses, and we employ a case study in Leipzig-Halle, Germany. The following five ecosystem services, which are of special importance for urban areas, were selected: local climate regulation, recreation potential, biodiversity potential, food supply, and above-ground carbon storage. These services were analyzed from 1990 to 2006. Our results identified only slight increases in urbanization $\left(1 \%\right.$ or $\left.3 \mathrm{~km}^{2}\right)$ and in mining restoration $\left(-11 \mathrm{~km}^{2}\right)$. However, the detected land use changes led to synergies with biodiversity and climate regulation of $>50 \%$ of the total area, whereas trade-offs of approximately $60 \%$ were detected between variables such as climate regulation and recreation. Finally, we address both the opportunities and the challenges that were encountered in the integration study, specifically with respect to the application in land use planning.
\end{abstract}

Key Words: Ecosystem services; Leipzig-Halle; synergies; trade-offs; urban regions

\section{INTRODUCTION}

Humans consume more natural resources and destroy more ecosystems than ever before, as was recently demonstrated for more than 150 countries worldwide (Guo et al. 2010). Ecosystems are part of the natural environment, and they support human life and the development of the societies by providing several goods and services (MA 2005, Hassan et al. 2005, Costanza et al. 1997, Daily 1997, De Groot 1992, De Groot et al. 2002). For example, agrarian ecosystems produce food; forests sequester carbon and deliver fiber and fuel; and functioning wetlands regulate water flows after extreme rainfall events, reduce the danger of floods, and clear polluted waters.

A number of studies regarding the theoretical, conceptual, and empirical approaches to ecosystem services (ES) have been conducted. For approximately two decades, these concepts have gained increasing attention and importance among scientists worldwide (Daily and Matson 2008, Lappé 2009, Burkhard et al. 2010). The first fundamental theoretical reflections were published by De Groot (1992) and Daily (1997). The growing popularity of the ES concept can be viewed as a reaction to the interplay between the long-term neglect of ecological functions and processes in our basic economic cycles, which is often considered to be gratis (Cox and Searle 2009), and to the growing devastation and degradation of the ecosystems (Boyd and Banzhaf 2007). After the publication of the results of the Millennium Ecosystem Assessment (MA 2005), which clearly showed a global ecosystem decline, it became obvious to the public that humankind depends on nature and ecosystems and the variety of functions, processes and fluxes. Another example of the growing understanding of the importance of ecosystem services for global policy is The Economics of Ecosystems and Biodiversity (TEEB) study (2010), which focuses on the economics of ecosystems and biodiversity. Recently, the issues of biodiversity and ecosystem services were brought to the attention of policy-makers; in June 2010, the Intergovernmental Science-Policy Platform on Biodiversity and Ecosystem Services (IPBES) was initiated in Busan, South Korea (http://www.biodiv-network.de).

Despite the progress in ES research (Andersson et al. 2007, Daily and Matson 2008), we still lack a satisfying and comprehensive understanding of the interactions and feedback among different ecosystem services. They may both support and impair each other, which suggests the presence of a range of synergies, trade-offs, and net losses (Rodríguez et al. 2006). Here, a trade-off refers to the increase of the provisioning of one ecosystem service and the simultaneous decline of another service at the same location. This knowledge determines the necessary implementation of the ES concept into society and political decision making in terms of assessing whether it is worthwhile, resource- and cost-efficient or sustainable to support the provision of one ecosystem services with regard to a possibly costly decline of another ES (Cox and Searle 2009, Haines-Young and Potschin 2010, Bastian et al. 2011, Holzkämper and Seppelt 2007, Seppelt and Voinov 2003). For planning purposes, a better understanding of the spatial patterns of ES, their trade-offs and their relationship to land

\footnotetext{
${ }^{1}$ Humboldt University Berlin and Helmholtz Centre for Environmental Research - UFZ, Germany, ${ }^{2}$ Helmholtz Centre for Environmental Research - UFZ, Germany, ${ }^{3}$ University of Massachusetts-Amherst, ${ }^{4}$ University of Kiel Ecology Centre
} 
cover change is absolutely necessary (Borgström et al. 2006, Egoh et al. 2009, Lautenbach et al. 2010). This is particularly true in urban regions, where today more than half of the world's population lives and which are predicted to continue to grow (UN 2008). In Europe today, more than $70 \%$ of the population lives in urban areas (Kabisch and Haase 2011). This number is likely to increase to $84 \%$ by 2050 . Urbanization and soil sealing have led to rapid changes in the biogeochemical cycles, hydrological processes and ecosystem functions (Bolund and Hunhammar 1999). In addition, human demands on urban ecosystems will increase in the next few decades due to the increase in population in these regions and the concentration of the world's economy (Raudsepp-Hearne et al. 2010). However, particularly in multifunctional urban regions, the assessment and integration of ecosystem services is challenging because we face a full range of overlaying ecosystem processes, functions, and respective services due to urban regions' dense, heterogeneous, and dynamic land cover patterns (Haase et al. 2010). Although urban ecology has made substantial progress in recent years regarding the specific ecological functions in urban areas, the explicit consideration of urban ES and their interaction with one another has not yet received much study.

Identification of synergies and trade-offs allows policymakers to better understand the hidden consequences of preferring one ecosystem service to another. Synergistic interactions allow for simultaneous enhancement of more than one ecosystem service. Because increasing the supply of one ecosystem service can enhance the supply of others (for example, forest restoration may lead to improvements in several cultural, provisioning, and regulating ecosystem services), the successful management of synergisms is a key component of any spatial development strategy that aims to increase the supply of ES for the well-being of humans.

Based on this background, our objectives were as follows: (a) to show an analytical framework of the different ways to integrate ecosystem service provisioning for an urban region and, in doing so, (b) to show the relationships between ES, such as synergies, trade-offs and net losses. We used the urban region of Leipzig-Halle in eastern Germany as a case study to provide a practical example of how to use this framework. Five ES that are of particular importance for urban ecosystems were selected: (1) local climate regulation, (2) recreation potential, (3) biodiversity potential, (4) food supply and (5) above-ground carbon storage.

\section{STUDY REGION}

With a population of $1,073,000$, the rural-urban region of Leipzig-Halle is an important region in eastern Germany. It is located in the federal states of Saxony and Saxony-Anhalt, and covers a total area of $4390 \mathrm{~km}^{2}$. Its two main urban cores, Leipzig and Halle, are surrounded by small towns and rural areas. Both cities have been the centers of commerce and trade since the $19^{\text {th }}$ century. Additionally, open cast lignite mining was developed around the cities at the turn of the $19^{\text {th }}$ century. The mining activities increased in scale due to the shortage of imports during the First World War, which led to the considerable reconfiguration of the region of Leipzig-Halle. A chemical industry developed that used the energy and raw materials from lignite mining. This development continued after 1949, when the Leipzig-Halle region became a part of the socialist East Germany (GDR), and it became a center for the chemical industries. During this time, major town extensions were realized. After the political changes of 1989 and the German reunification in 1990, the economy of the region declined in the face of national and international competition (Nuissl and Rink 2005). Today, tentative new developments occur in the service sector, such as in the fields of education, transportation, tourism and leisure. Although the region of Leipzig-Halle belongs to two different federal states and is governed by a variety of administrative bodies, it is a complete, functioning region.

Fig. 1. Evaluation matrix to determine the synergies, tradeoffs, losses, win-no change, lose-no change and no change (at the zero-point of the diagram) and the interrelations of bundles of ES in the rural-urban region that was driven by land-use change.

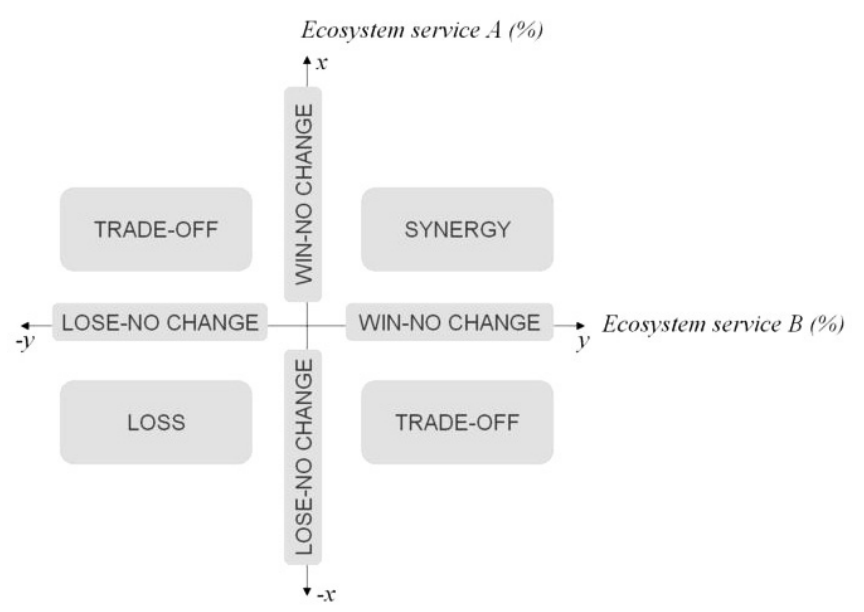

The Leipzig-Halle region has faced population loss since the 1970s, and this loss still continues today (Nuissl and Rink 2005). A spatially differentiated pattern of population development has been observed since 1990. Due to suburbanization and out-migration, Halle lost $20 \%$ of its inhabitants between 1990 and 2000, and its population continues to decline. Leipzig's population declined $12 \%$ between 1990 and 2000, but it increased 2.7\% between 2000 and 2006 (Saxon Office of Statistics 2010). The opposing 
Fig. 2. Design of the integration framework. Based on the land-use, different ES provision maps were calculated. The spatial integration of the trade-offs was performed at three levels. The total region was used as a zonal analysis to distinguish the urban, peri-urban and rural areas and to produce spatially explicit maps. The temporal integration was analysed using a change detection of the ES interactions of two different time periods.

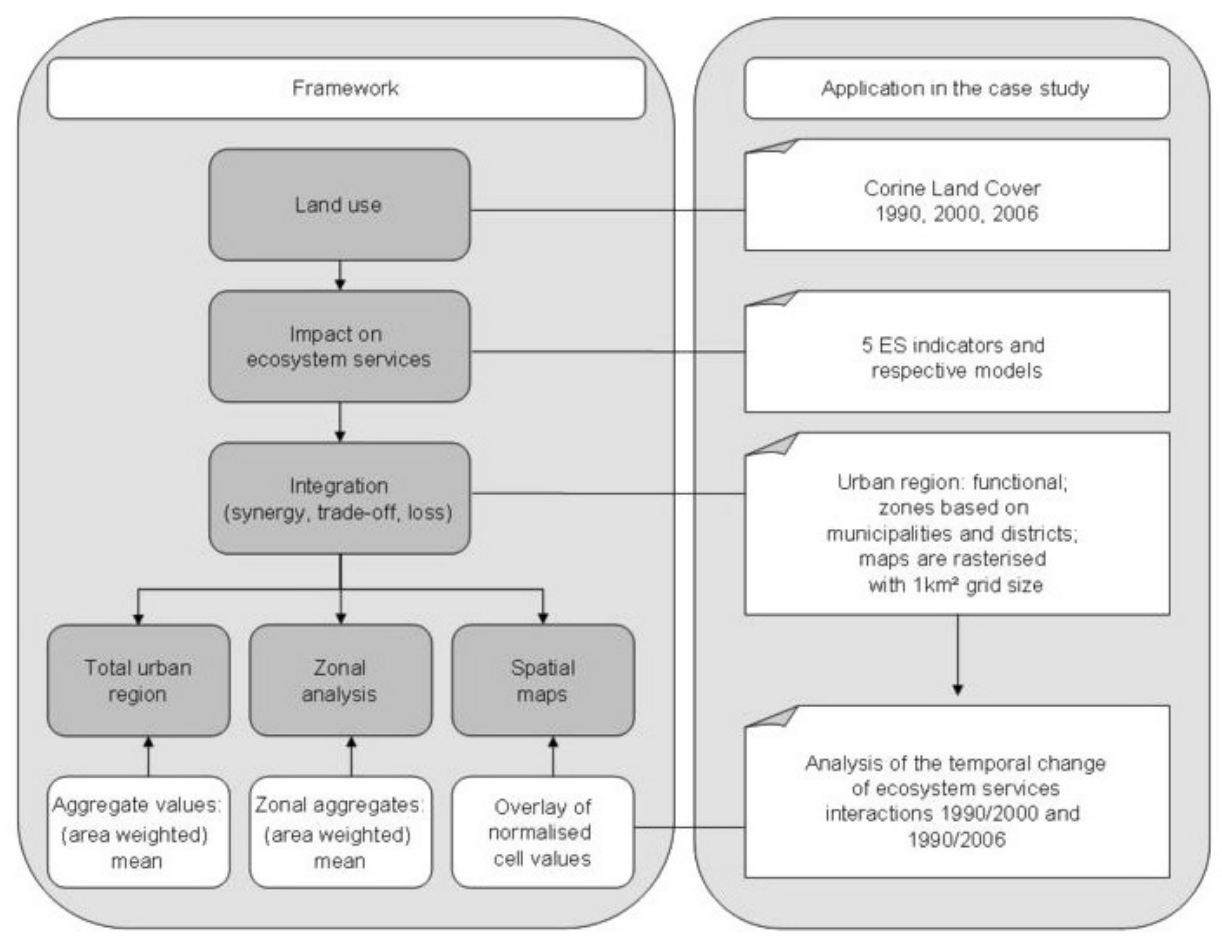

tendencies of the peri-urban and urban population development are striking. Since 2000, a downward trend in the entire area has been evident. Today, a general shrinking of the population can be observed, except in the city of Leipzig.

Leipzig-Halle is a complex urban region because it exhibits simultaneous urban land use growth and shrinkage. Although the postsocialist transformation period that included a heavy urban sprawl has passed, the moderate, urban land use development in the peri-urban region currently continues (Haase and Nuissl 2010). At the same time, considerable sections of the inner city have faced a population outflow that was followed by a residential vacancy (currently approximately 40,000 flats), the creation of large urban brownfields that comprise approximately $7 \mathrm{~km}^{2}$ and the massive underutilization of the urban infrastructure (Haase and Nuissl 2007, Rink 2009). Since the early 1990s, the urban cores predominantly exhibited residential infill development close to the vacancies and urban brownfields (Haase and Nuissl 2010). The inner peri-urban and outer peri-urban regions are principally characterized by different forms of residential and commercial sprawl (Haase and Nuissl 2007, Haase and Nuissl 2010). The commercial development occurred along the axis between Leipzig and Halle. Since the late 1990s, the residential and commercial sprawl around Leipzig-Halle has abated considerably. Finally, after the rural redensification and intensification of arable production in the 1990s, a growth of biofuel production and the ongoing loss of arable land due to residential and commercial sprawl are observable. Remarkable changes occurred in the former mineral extraction sites, where the large, lignite, opencast mines have been converted into large lake areas and restored arable or forest lands (Schwarz et al. 2011a).

\section{INTEGRATIVE ANALYSIS OF URBAN ECOSYSTEM SERVICES}

\section{State of the Art}

Few studies have integrated different ecosystem services in their analyses (Seppelt et al. 2011a). Of the different possible interactions of ES, most studies have focused on trade-offs. In general, a trade-off is a balance that is achieved between two desirable but incompatible states or situations. Within the scope of the ecosystem services, trade-offs involve losing one quality but gaining another. The ES trade-offs arise from the land use and management choices that intentionally or unintentionally change the type, magnitude, and relative mix 
of the functions that are provided by ecosystems. Different definitions of trade-offs as they relate to ecosystem services can be found in the literature. Bennet et al. (2009) and Raudsepp-Hearne et al. (2010) define a trade-off as the simultaneous reduction in one ecosystem service and the enhancement of another. Conversely, synergy is when two ecosystem services are enhanced. This definition focuses on the interaction between the ecosystem services and their temporal changes in the same region. Another approach by Rodríguez et al. (2006; also followed by Seppelt et al. 2011a) uses three axes for the classification of trade-offs: spatial scale, temporal scale, and reversibility. The spatial scale refers to whether the effects of the trade-off are felt locally or at a distant location. The temporal scale refers to whether the effects take place relatively rapidly or slowly. "Reversibility expresses the likelihood that the perturbed ES may return to its original state/ functionality in case the perturbation ceases" (Seppelt et al. 2011a).

Integrated ecosystem services studies that are not limited to trade-offs use diverse schemes for analysis. Steffan-Dewenter et al. (2007) calculated the trade-offs between income, biodiversity, and ecosystem functioning at the plot level for one point in time. Another study by Egoh et al. (2009) examined five ES and species richness in South Africa; the authors produced spatially explicit maps of the ES and species richness, and they determined the percentage of service and species coverage in the subzones (biomes or quarter-degreesquares) for one point in time.

Bennett et al. (2009) compare the interaction of the ecosystem services in a framework that revealed two types of interactions: first, one driver affects several ecosystem services, and second, interactions occur between ecosystem services. RaudseppHearne et al. (2010) identified bundles of ecosystem services that repeatedly appear together in Canada on the landscape scale. In their analysis of municipalities in Quebec, the authors mapped the spatial patterns of the ecosystem services and their interactions in the form of correlations between the different ecosystem services in the respective municipalities. Raudsepp-Hearne et al. (2010) found synergies in the form of positive correlations and trade-offs in the form of negative correlations. Moreover, the authors identified bundles of ecosystem services in municipalities based on a cluster analysis (cf. supplementary material of Raudsepp-Hearne et al. 2010).

\section{An analysis framework for integrating urban ecosystem services}

A common framework for analysis requires a definition for repeated terms. In this paper, based on the definitions of Bennet et al. (2009) and Raudsepp-Hearne et al. (2010), we define the following interactions between ecosystem services within a region (Figure 3):

1. Synergy: a win-win situation that involves a mutual improvement of both ecosystem services,
2. Win-no change: An improvement in one ecosystem service and no obvious changes in the other,

3. Lose-no change: A decline in one ecosystem service and no obvious changes in the other,

4. Trade-off: A win-lose or lose-win situation that involves losing one ecosystem service in exchange for gaining another,

5. Loss: A mutual loss of ecosystem services and

6. No change: No changes in any of the considered ecosystem services.

Fig. 3. Land-use map of the study region of Leipzig-Halle. The boundary between the two federal states of SaxonyAnhalt and Saxony is indicated with a black line. Data: Corine Land Cover 2006 (EEA).

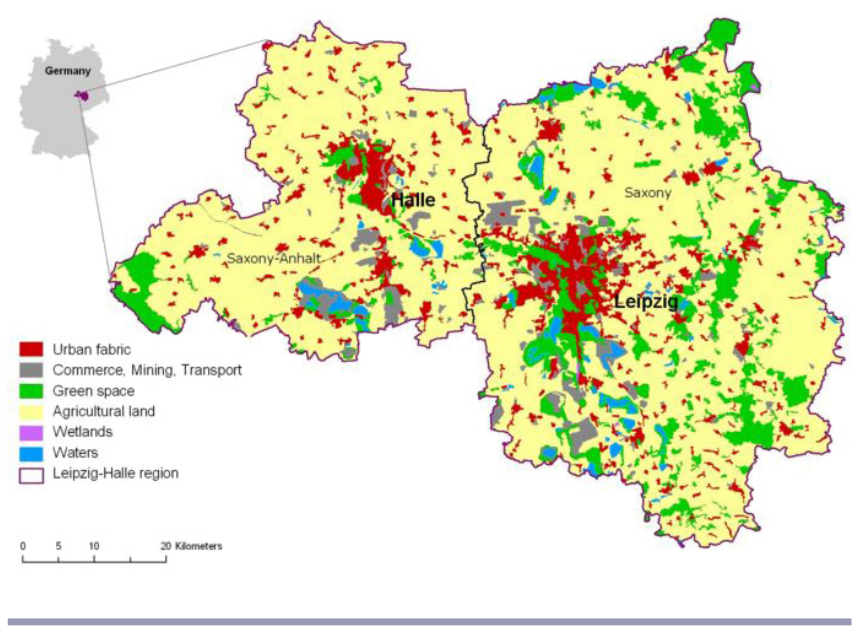

In this framework, synergies, trade-offs and losses were considered only within a region; they were not considered outside the region. This implies that the impacts of decisions within the region on the provision of ecosystem services somewhere else (called spatial trade-offs by Rodríguez et al. 2006, or off site effects by Seppelt et al. 2011a) are not covered here. We calculated synergies, trade-offs, and losses between ES based on a respective land cover state. The trade-offs over time, as defined by Rodríguez et al. (2006), were analyzed such that a land cover decision at the current state would determine an ecosystem services trade-off in the future. Finally, land cover is the main driver in this framework to influence ES provision. However, scenarios with a focus on other drivers, such as climate, could also be analyzed in the framework if these drivers also led to distinct impacts in the respective ES models.

Our spatially explicit analysis framework that was used to integrate urban ES consisted of the following four three steps. (i) Land cover change detection: because land cover is the 
most dynamic component of urban regions and has the highest respective impact on ecosystems, we used Corine land cover data from 19902000 and 2006 to detect the land cover change (EEA 2007). (ii) ES modeling: based on these land cover and land cover change data and the assumption that the type of each urban land cover determined the ecosystem services provision, five ecosystem services were quantified using models. The total values for these ES were calculated for all three periods. (iii) Integrated analysis: the third step of the integration framework represents the actual integrated analysis. The standardized data for the two time periods, 1990-2000 and 1990-2006, were analyzed concerning an increase or decrease of the ES fulfillment at a $1 \times 1 \mathrm{~km}$ cell raster level by setting the value of 1990 to $100 \%$ (Figure 4).

Fig. 4. The sub-regional "zonal" division of the study region of Leipzig-Halle that was used for the spatial aggregation of the zonal assessment of rural, peri-urban and urban areas.

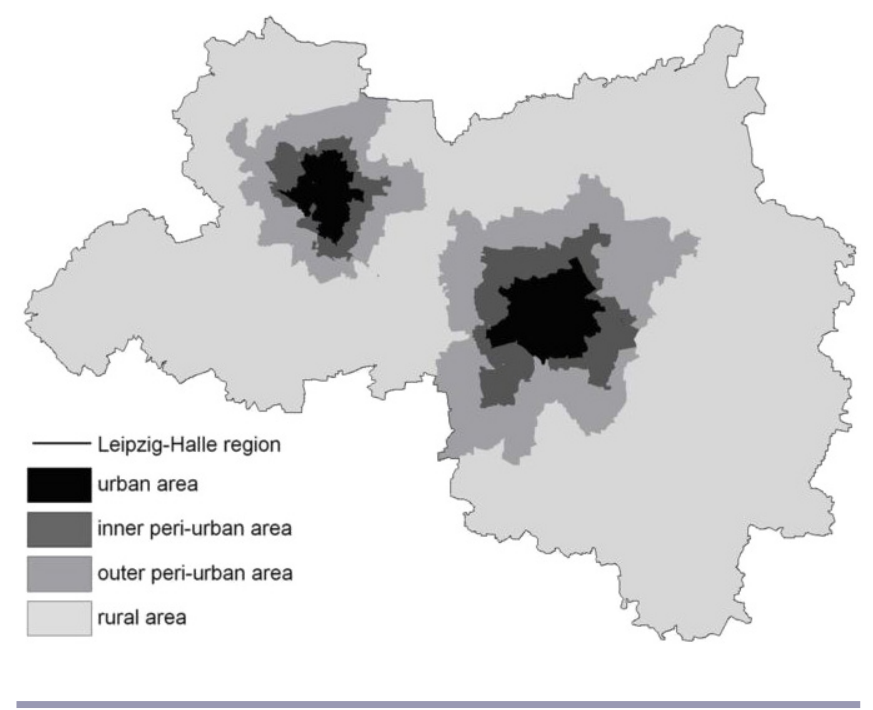

The upscaling to the larger grid should account for uncertainties in the underlying data sets and methods. However, the initial calculations for each ES were performed on the original $100 \times 100 \mathrm{~m}^{2}$ grids of Corine land cover. The cells were coded as follows: a cell value $>105 \%$ indicates an increase in the ecosystem service provision; a cell value $<95 \%$ indicates a decrease; for all other values, there are no changes that are outside an uncertainty range of 5\%. Afterwards, the raster maps were compared pair-wise to determine synergies, trade-offs or losses between all five ecosystem services. Finally, we determined the changes in the six interaction categories that are defined by comparing the cell statuses in 2000 or 2006 to the statuses from 1990.

The ecosystem services integration was carried out at three spatial aggregation levels: total urban region, zone assessment (see Figure 4), and spatial maps. First, in the entire urban region, the relative changes of the mean values were used. Assuming values from 1990 were $100 \%$, the values $>105 \%$ implied an increase of the ecosystem service provisioning compared to 1990 , and the values $<95 \%$ implied a respective decrease. Second, an analysis on the urban and the inner and the outer peri-urban parts of the region ("zones") was performed using the mean values per zone. Here, a change $\geq 5 \%$ compared to 1990 indicated an improvement in the respective ecosystem service in the respective zone, and a change $\leq 5 \%$ compared to 1990 indicated the opposite. Third, a spatially explicit evaluation of the ecosystem services' provisions and their dynamic trade-offs was conducted at the $1 \mathrm{x} 1 \mathrm{~km}$ raster level by comparing pairs of ecosystem services maps (see Figure 4). Here, positive and negative derivations of the ecosystem services values compared to 1990 were identified for each ecosystem service separately. Subsequently, pairs of ecosystem services were compared to determine whether the land cover change led to a positive or negative impact on the services' fulfillment.

Following our spatial analysis framework, the study region of Leipzig-Halle is divided into four different zones that were based on the indicators of administrative structure (the urban area in its administrative borders and other municipalities), population density and built-up density (Figure 2). The administrative boundary of the two cities encompasses (1) the urban parts that comprise the most densely built-up areas of the two cities and (2) the inner peri-urban areas, which are characterized by lower population densities, discontinuous urban fabric and primarily commercial activities (cf. a definition by EEA 2007). Around the administrative boundaries of the two cities are (3) the outer peri-urban areas, which are characterized by their higher population densities and higher densities of built-up areas compared to (4) the rest of the region. The remaining parts of the region are composed of rural areas that contain the lowest population and building densities. The rural areas are dominated by arable production and small towns that serve as local centers.

\section{DATA AND METHODS}

\section{Land cover data}

As mentioned above, the Corine land cover (CLC) dataset for the years 1990, 2000, and 2006 was used in this study. The data are issued by the European Environment Agency (EEA), which is publicly available. The spatial resolution is $100 \times 100$ $\mathrm{m}$, and the minimal mapping unit (MMU) is 25 ha. Table 1 provides an overview of the land cover classes and their changes from 1990 to 2006 from our case study.

In relation to our interaction framework, the examination of transitions from the no-change category into synergies, tradeoffs or losses between 1990-2000 and 1990-2006 indicate the continuity of the ES provisioning as it depends on changes in land cover. Transitions, such as changes from win/lose-no 
Table 1. Land-use class distribution and development in the Leipzig-Halle region in $\mathrm{km}^{2}$ for 1990, 2000, and 2006 (data source: The European Environment Agency 2010).

\begin{tabular}{|c|c|c|c|c|}
\hline Land-use class & Description & 1990 & 2000 & 2006 \\
\hline Continuous urban fabric (111) & Built-up settlement land, mostly inner-urban compact residential areas & 8.36 & 8.36 & 8.47 \\
\hline Discontinuous urban fabric (112) & $\begin{array}{l}\text { Built-up settlement land, mostly peri-urban and rural low density } \\
\text { residential areas }\end{array}$ & 340.86 & 356.40 & 367.53 \\
\hline $\begin{array}{l}\text { Industrial or commercial units } \\
\text { (121) }\end{array}$ & Predominantly built-up industrial and commercial land & 65.50 & 89.29 & 94.94 \\
\hline $\begin{array}{l}\text { Road and rail networks and } \\
\text { associated land (122) }\end{array}$ & Transportation area, often sealed & 4.60 & 4.60 & 4.55 \\
\hline Airports (124) & Predominantly built-up and sealed area of airports & 11.94 & 16.68 & 19.81 \\
\hline Mineral extraction sites (131) & Area of opencast lignite mining, predominantly bare soil and sediments & 144.08 & 97.62 & 61.60 \\
\hline Dump sites (132) & All forms of dumps, mostly material and relief accumulation; unsealed & 8.55 & 6.88 & 5.89 \\
\hline Construction sites (133) & Land development and preparation area & 0.46 & 2.13 & 2.92 \\
\hline Green urban areas (141) & $\begin{array}{l}\text { All forms of urban green spaces including parks, allotment gardens, } \\
\text { cemeteries etc.; predominantly not sealed }\end{array}$ & 31.13 & 31.13 & 35.18 \\
\hline Sport and leisure facilities (142) & $\begin{array}{l}\text { All forms of leisure areas; partly built-up, open spaces such as } \\
\text { sportsgrounds often with densified bare soils }\end{array}$ & 14.02 & 14.02 & 20.05 \\
\hline Non-irrigated arable land (211) & Arable production land & 2827.85 & 2770.97 & 2700.22 \\
\hline $\begin{array}{l}\text { Fruit trees and berry plantations } \\
(222)\end{array}$ & Arable plantations & 26.73 & 8.32 & 8.54 \\
\hline Pastures (231) & Grassland, partly wetlands & 99.01 & 95.82 & 118.11 \\
\hline Complex cultivation patterns (242) & Including gardens, greenhouses, tree nurseries etc. & 4.18 & 7.31 & 7.80 \\
\hline Deciduous forest (311) & Deciduous forests and young forest plantations & 301.66 & 303.11 & 310.75 \\
\hline Coniferous forest (312) & Coniferous forests and young forest plantations & 4.98 & 4.04 & 4.11 \\
\hline Mixed forest (313) & Mixed forests and young forest plantations & 22.21 & 21.91 & 28.64 \\
\hline
\end{tabular}

change to synergy/trade-off/loss, also indicate temporally delayed potentials of synergies, trade-offs, and losses, as well as the challenges of losing synergistic effects.

\section{Ecosystem services indicators}

The indicators that were used for the ecosystem services were calculated using simple and robust methods from published literature, or they were based on empirical data. The methods are comprehensible and reproducible by regional and local planners. Table 2 provides a summary of the indicators. Details are provided in Appendix 1.

\section{Local climate regulation}

Local climate regulation is an important urban ecosystem service. Green areas, such as parks, urban forests, lawns and gardens and the waters of streams, lakes and ponds provide fresh, cool air for the population (Tratalos et al. 2007, Whitford et al. 2001). Accordingly, the local climate regulation is a valuable service provided by ES for the inhabitants of an urban region because it reduces the urban heat island effect, and therefore, it is important for maintaining the quality of life and adapting the rural and urban regions to climate change. The best indicator of local climate regulation would be a map of air temperatures for the urban region. However, air temperatures can only be directly assessed with stationary or mobile measurements, or they can be indirectly estimated with climate models (Stewart 2011). Thus, land surface temperatures are often used as proxies for direct measurements (Schwarz et al. 2011b). We used land surface thermal emissions, which indicate the total amount of energy emitted by a surface. The land surface emissions stem from the Landsat remote sensing data. A lookup table was created to link landcover classes to the land surface emissions (Schwarz et al. 2011a). An index of the thermal emissions of each land-cover type was normalized by the thermal emissions of forests, so that the index equals 1 for forests (Table 2). This lookup table was then used with the land-cover maps from this study to compute the spatial distribution of the emission index, and thereby, to estimate local climate regulation for all time steps. Any uncertainties in the surface emission values were accounted for by the mean +/- 1 standard deviation of emissions for each land cover class, and they were lower than $5 \%$ (for details see Table A1).

\section{Above-ground carbon storage}

Terrestrial carbon, which is stored in living and dead biomass and in soils, is an important part of the global carbon cycle. Atmospheric carbon can be sequestered into the terrestrial stock and then released. With the exception of soil, vegetation is the largest pool of organic carbon in urban ecosystems (Churkina 2008). Although it is difficult to measure the carbon in soil and the changes in carbon storage are hard to predict, the stock and changes of the above ground stock are easier to estimate. Most of the above ground carbon can be found in trees (Davies et al. 2011). The amount of tree cover and, therefore, the amount of stored carbon, varies across different land-cover types and geographical regions. The land-cover changes that result from the destruction of trees leads to the release of carbon into the atmosphere and vice versa. Land- 
Table 2. Overview of the indicators and models that were used to calculate the ES (the detailed model descriptions and information can be found in Appendix 1).

\begin{tabular}{|c|c|c|c|}
\hline Ecosystem service & Indicator and Unit & Model description & Reference \\
\hline Local climate regulation & Surface emissivity [index] & $\begin{array}{l}\text { Look-up table with land surface } \\
\text { emissivities per land-use type }\end{array}$ & Schwarz et al. (2010) \\
\hline Recreation potential & Green space per capita $\left[\mathrm{m}^{2} /\right.$ person] & $\begin{array}{l}\text { Total available green space per raster } \\
\text { cell divided by the number of people } \\
\text { living there }\end{array}$ & Haase et al. (2011) \\
\hline Carbon mitigation & $\begin{array}{l}\text { Above ground carbon storage } \\
{\left[\mathrm{MgCO}_{2}\right]}\end{array}$ & $\begin{array}{l}\text { Extrapolation of field data for carbon } \\
\text { storage in trees }\end{array}$ & Strohbach et al. (2011) \\
\hline Biodiversity potential & $\begin{array}{l}\text { Habitat potential for bird species } \\
\text { [index] }\end{array}$ & $\begin{array}{l}\text { Regression model for land-use type } \\
\text { (bird species) }\end{array}$ & Strohbach (2010) \\
\hline Food supply & Food supply [GJ/ha] & $\begin{array}{l}\text { Regression model for land-use and } \\
\text { soil types (yield) }\end{array}$ & Kroll et al. (2010) \\
\hline
\end{tabular}

cover change in rural-urban regions is, therefore, directly linked to the global carbon cycle and climate change (see Davies et al. 2011). In the summer of 2009, 190 plots that each had a radius of $15 \mathrm{~m}$ were sampled within the urban region of Leipzig. All trees that had a diameter at breast height above 5 $\mathrm{cm}$ were measured, and their biomass was derived using allometric equations. The exact procedure is described in Strohbach and Haase (2012). The original survey was carried out with more detailed land-cover that included 19 land-cover classes. To transfer the above-ground carbon values from Strohbach and Haase (2012), we first intersected the two landcover layers in a GIS. Then, we calculated the new storage values for the Corine land cover classes as the area-weighted averages of the values from Strohbach and Haase (2012).

\section{Biodiversity potential}

Biodiversity is usually not counted as a service but rather is viewed as the basis for ecosystem service production (MA 2005); this is what makes biodiversity so important. In addition, several studies in cities have shown that urban dwellers directly benefit from the presence of rich biodiversity within their neighborhoods (Baines 2000, Fuller et al. 2007, Mitchell and Popham 2008). Some studies have estimated the value of individual species. Rather than estimating the value of single species, we used indicator species to assess the biodiversity potential. Achtziger et al. (2004) selected indicator species for monitoring sustainable development of five major habitat types in Germany for the German Federal Agency for Nature Conservation. All indicators are bird species that represent a good ecological state of these habitat types and are sensitive to changes. Two detailed breeding bird surveys are available for the region: a breeding bird survey from Halle and the surrounding areas from 1989 with a spatial resolution of 1 x $1 \mathrm{~km}$ (Schönbrodt and Spretke 1989), and a breeding bird survey from Leipzig and the surrounding areas from 1993 with a spatial resolution of $0.5 \times 0.5 \mathrm{~km}$ (STUFA 1995). The indicator species from both surveys were digitized, and the survey from Leipzig was resampled to $1 \mathrm{x} 1 \mathrm{~km}$. Rare species were removed from the data set. Six agricultural species and five forest species were selected (see Table A4). Habitat models that used the statistical relationships between land cover and the presence or absence of the indicator species were developed. In addition to the proportion of land cover, the average summer temperature and precipitation (DWD 2010), and the total river length (ATKIS 2006) in each cell were included in the model. The machine learning technique randomForest (Liaw and Wiener 2002, Hastie et al. 2009) was used to create a model that predicted the probability that each raster cell would be occupied by each bird species. The probability that a certain grid cell was occupied by a species was predicted for the land cover from 19902000 and 2006; the climate data and river length were assumed stable at 1990 values. From the individual probabilities, the mean probabilities of occurrence were calculated for all six agricultural and five forest species and the probabilities were between 0 and 1 for both habitat types. If, for example, the value of an agricultural indicator is close to 0 , the grid cell is unlikely to be occupied by any of the respective indicator species, and it is considered to have no value for agricultural biodiversity. If the value is close to 1 , all six agriculture indicator species are very likely to occur in the cell, and therefore, the grid cell is likely to have a high value for agricultural biodiversity. Finally, we created a biodiversity map that contained values between 0 and 1 using the highest value of either the agricultural or the forest biodiversity indicators (Table 2).

\section{Food supply}

Food supply is crucial for both food security and the overall resilience of an urban region (Jansson and Polasky 2010). Food supply was quantified in $\mathrm{GJ} / \mathrm{ha}$ for each land-cover type. Statistical data at the administrative district level, on crop yield per hectare, crop type (wheat, rye, barley, oat, triticale, silage maize, fodder grass, rape seed, turnips or potatoes), fruit yield per hectare, fodder grass yield per hectare, and the game and fish killed per year for the years 1991, 2000, and 2007 were employed to calculate average values of food production per hectare for the each land-cover type in each year. The amount 
of grass produced per hectare of pasture was converted into the levels of meat and milk that can hypothetically be produced with the fodder from this area. For pastures, forests, fruit trees and berry plantations, the average food supply values were calculated per hectare of land-cover type at the federal state level because of missing data at the administrative district level. In regards to food production on arable land, average yields per hectare were calculated at the administrative district level. The yield and soil fertility data were provided by the Statistical Office of the Free State of Saxony (Saxon Office of Statistics, 2010), Saxon State Agency for Environment and Geology (2007) and the Environmental Agency of SaxonyAnhalt (2008). The percentage of non-food crop production, such as bio-energy crops on arable land, was estimated with information from the Ministry of Agriculture and Environment Saxony-Anhalt $(2002,2007)$ and the Saxon State Ministry of the Environment and Agriculture (2007). . With these data, it was possible to consider the increase of bioenergy crop production and to only restrict the food supply calculation on food crops. Soil fertility maps with a scale $1: 200,000$ that contained an index of the soil's yield potential from 1 to 5 were applied to differentiate the food production on arable land according to the soil fertility (cf. Kroll et al. 2012). A bivariate regression and correlation analysis was conducted to investigate the relationship between the aggregated soil fertility index and the crop yield with $n=24$ administrative districts in Saxony and Saxony-Anhalt. The results were corrected using the soil fertility maps and the determined regression curves for those crops and years that showed a significant correlation between the crop yield and the soil fertility index. After the calculation of the food production in tonnes per hectare, this value was multiplied with the caloric value of the respective food based on the standard nutritive factors provided by the United Nations FAO statistics database (FAO 2009). An uncertainty analysis was not feasible in this case (see Tables A1 and A2). Although imports and exports of food play an important role in the region, the trade flows of food could not be considered here. Thus, the calculated potential food supply should not be assumed as actual food supply, which is composed of regionally produced and imported food. However, the consideration of the statistical data on productivity and crop type composition described above indirectly reflects other effects, such as the impact of market conditions and subsidies on the regional agricultural production. For a more detailed description of the methodology and the data applied, see Kroll et al. (2012).

\section{Recreation potential}

Urban green spaces provide recreation and aesthetic potential (Bolund and Hunhammer 1999, Troyer 2002, Breuste 2003, Yli-Pelkonen and Nielema 2005), and therefore, they play an important role in determining the quality of life for the urban residents (Santos and Martins 2007, Priego et al 2008).
Because city regions are 'people places', the attempts to preserve nature and ecosystems within the city regions can only be successful if they meet the needs and the wishes of the residents. To calculate the recreation potential in the urban region, the area of urban green spaces was used as a proxy for the recreation space (reclassified Corine land cover codes 1.4.1. and 1.4.2 in Table 2). All forests were included in the recreation classes because they are state forests and they are publicly accessible. In addition, lakes and waters in the urban and peri-urban zones were assigned as urban recreation areas, and they were included in the analysis. Other water bodies and arable land were excluded because they do not provide recreation space and are not visited for this purpose by people. The recreation potential was determined by dividing the total urban green space in a local, municipal district by the number of residents. The delineated green space, which is used for recreation, is all publicly accessible. In 5 local districts, the classified green spaces were compared to the actual green spaces, and the uncertainties in the green space classifications were very low $(<1 \%)$. The population numbers were based on census data, and thus, they provide the highest possible validity. The systematic errors of the annual census data for Leipzig are estimated to be $+/-5 \%$ (Leipzig 2011 - Statistical Office).

\section{RESULTS OF THE CASE STUDY}

\section{Aggregated ecosystem services in an urban region}

At the aggregated level for the whole urban region, we observed that for most ecosystem services, the more major value changes occurred in the time period from 1990 to 2000 compared to the 1990 to 2006 period. For above-ground carbon storage only, significant increases were found for the year 2006. This finding corresponds to the change of land cover that is shown in Table 1. In regards to the interactions of the five ecosystem services, we identified ecosystem service trade-offs between recreation potential, which decreased, and all of the other ecosystem services, which did not change significantly (Figure 5).

The analysis on a zone-by-zone basis revealed the effects of both the peri-urbanization processes in the urban regions of Leipzig and Halle and the restoration in the lignite mining area in the south of Leipzig and Halle. Particularly, the intensification of agricultural production after 1990 increased the provisioning of the food supply, but there was an overall decline in green space in the inner and outer peri-urban parts of the Leipzig-Halle region. The resulting trade-off was the decline in the open and grassland recreation areas in the periurban parts of the region and thus, of the recreation potential (Figure 6). This increase in food production can be viewed also as a consequence of partial privatization of the agrarian sector after the political transition in 1990 that included a return of collectivized land to former owners. In addition, above-ground carbon storage increased in the peri-urban 
regions due to the conversion of treeless agricultural fields into residential areas with green space and due to the afforestation of the former lignite mining areas. However, compared to a forest, afforestation has no recreational value after 16 years and was therefore not included in the recreation potential calculation.

Fig. 5. Aggregated view of the ecosystem service provisioning in the urban region of Leipzig-Halle for different land-use states from $1990(=100), 2000$ and 2006. > 100 indicates an increase compared to 1990, and < 100 indicates a respective decrease compared to 1990 . The small bars represent the uncertainty of the model results and not the value range as depicted in Figure 8.

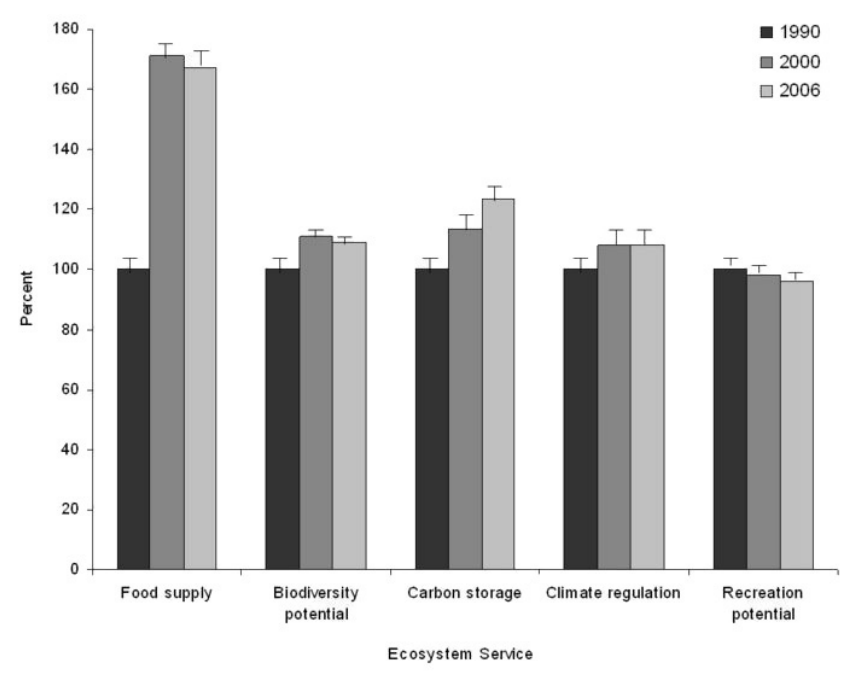

Fig. 6. Zonal integration of the provisioning of five ES in the urban, inner peri-urban, outer peri-urban and rural parts of the urban region of Leipzig-Halle for the different landuse states. The proportional change for the years 2000 and 2006 were each compared to 1990.

\begin{tabular}{|c|c|c|c|c|c|c|c|c|}
\hline \multirow[t]{2}{*}{ Ecosystem Service } & \multicolumn{4}{|c|}{1990 to 2000} & \multicolumn{4}{|c|}{1990 to 2006} \\
\hline & Rural & \begin{tabular}{|c|} 
Outer \\
peri-urban \\
\end{tabular} & \begin{tabular}{|c|} 
Inner \\
peri-urban
\end{tabular} & Urban & Rural & \begin{tabular}{|c|} 
Outer \\
peri-urban
\end{tabular} & \begin{tabular}{|c|} 
Inner \\
peri-urban \\
\end{tabular} & Urban \\
\hline Food supply & $\uparrow$ & $\uparrow$ & $\uparrow$ & $\downarrow$ & $\uparrow$ & $\uparrow$ & $\uparrow$ & $\downarrow$ \\
\hline Biodiversity potential & $\leftrightarrow$ & $\leftrightarrow$ & $\uparrow$ & $\leftrightarrow$ & $\leftrightarrow$ & $\downarrow$ & $\uparrow$ & $\leftrightarrow$ \\
\hline Recreation potential & $\leftrightarrow$ & $\downarrow$ & $\downarrow$ & $\uparrow$ & $\leftrightarrow$ & $\downarrow$ & $\downarrow$ & $\leftrightarrow$ \\
\hline Climate regulation & $\leftrightarrow$ & $\leftrightarrow$ & $\downarrow$ & $\leftrightarrow$ & $\leftrightarrow$ & $\leftrightarrow$ & $\downarrow$ & $\leftrightarrow$ \\
\hline Carbon storage pot. & $\leftrightarrow$ & $\uparrow$ & $\uparrow$ & $\leftrightarrow$ & $\leftrightarrow$ & $\uparrow$ & $\leftrightarrow$ & $\leftrightarrow$ \\
\hline \multicolumn{9}{|c|}{$\leftrightarrow$ less than $+/-5 \%$ change compared to 1990} \\
\hline \multicolumn{9}{|c|}{$\downarrow-5 \%$ or more change compared to 1990} \\
\hline \multicolumn{9}{|c|}{$\uparrow+5 \%$ or more change compared to 1990} \\
\hline
\end{tabular}

We interpret that the synergies, trade-offs and losses of the ecosystem services share drivers, such as the peri-urbanization and the restoration and intensification of agricultural production. This type of analysis can determine where most of the changes occur, namely in the peri-urban areas, and it can consequently determine where it is feasible to support synergies or avoid trade-offs by steering and planning the landcover changes.

In their bird diversity assessment of Leipzig, Strohbach et al. (2009) also identified that recreation potential has a considerable correspondence with bird species diversity. With this overlap as an example, the overall level of congruence among areas of high provisioning that also have at least two, but up to all five, services is an indication that these services are driven by similar variables. Thus, the ecosystem services enhancement and improvement strategies could be bundled to achieve a higher level of efficiency. The trade-offs that were found in our analysis indicate the contrary, which means that to avoid the trade-offs, different protection or conservation strategies are required.

We identified synergies for the food supply and above-ground carbon storage potential for the outer peri-urban regions in 2000 and 2006 that resulted from the restoration processes. They were realized as a large extent of agricultural re-use and afforestation (approximately 5\% of the total area) in the former mining areas. Therefore, the mining areas have a large potential to provide ecosystem services after they are recultivated. Losses existed for the service of climate regulation in the inner peri-urban areas as a consequence of soil sealing due to the peri-urbanization of approximately $7 \%$ of the total area. This finding is consistent with Schwarz et al. (2011a), who found that highly sealed surfaces exhibit high surface emissions and low evapotranspiration, which are consistent with their higher air temperatures and low climate regulation potential. The re-urbanization processes in the urban centers and suburbanization resulted in the loss of food supply in those regions through a decline in the agricultural area, and at the same time, the restoration of brownfields led to an increase in the recreation potential in the inner parts of the cities. The driver of this development was the interim use of the run-down areas in the cities as a cost-effective solution to fight urban blight and shrinkage. A study by Rall and Haase (2011) suggests that interim use has the potential to increase both the amount and the diversity of green spaces and to create new spaces for creative play and leisure activities. Brownfields are not detected in Corine land cover data, but a change from class 121 (industrial or commercial units) into 141 (green urban areas) in the inner urban parts of the cities indicated this transformation process.

To summarize, we detected a balanced number of synergies and losses at the zone assessment level compared to the whole region aggregate. In approximately $50 \%$ of all possible 
ecosystem service pair combinations in the zone-by-zone assessment, we found that the changes between 1990 and 2000 and between 1990 and 2006 were lower than 5\%.

\section{Spatial ecosystem services assessment}

Although there were similarities among the spatial patterns of the different services (e.g., floodplain forests provide both recreation and above-ground carbon storage), mapping the spatial distributions of the provisions of each ecosystem service revealed that their individual patterns were specific. By examining the spatial configuration of synergies, tradeoffs and losses in Figure 7 and the accumulated values in Figure 8, we found that ecosystem services were clustered in relation to two factors: the geographical position or degree of centrality in the region (urban, peri-urban, rural) and the land cover that integrated a range of human activities in the urban region (e.g., residential and commercial land cover types represent human activities such as living and housing and the labor market). Overall, the spatially explicit analysis of ecosystem services synergies, trade-offs and losses showed that the number of cells that exhibited one of these three states increased from 2000 to 2006 from $<20 \%\left(880 \mathrm{~km}^{2}\right)$ to $>35 \%$ $\left(1540 \mathrm{~km}^{2}\right)$ of the total area.

Specifically, we identified trade-offs among the ecosystem service provisions of food supply and climate regulation $(12 \%$ of the total area). We identified synergies between the biodiversity potential and above-ground carbon storage $(33 \%)$. Because the major land cover changes, which include an increase in imperviousness, have occurred in the inner and outer peri-urban areas of the many large cities in eastern Germany since 1990 (Haase and Nuissl 2010) (a total area of approximately $44 \mathrm{~km}^{2}$ ), most of the synergies, trade-offs, and losses of ecosystem services in our case study were identified in those areas. However, the spatial patterns are heterogeneous and diverse, and they depend on the single ES pair or bundle. In the urban parts of the region, net food supply losses were recorded in 2000 and 2006 (17\% of the total area, or $80 \mathrm{~km}^{2}$ ) due to the sub/peri-urbanization of formerly agrarian land in the outer regions of Leipzig and Halle. We identified a considerable number of potential trade-offs that would increase food supply and decrease recreation potential in the central northern and southern parts of the urban region where the less fertile soils are found (> 7\% of the total area). Regardless of their fertility, many plots of soil fell fallow after the political change in 1990 due to de-investment and land abandonment. However, this situation changed after the agriculture in eastern Germany recovered in the later portion of the 1990s (Nuissl and Rink 2005). The increase in food supply is a direct consequence of this development. In terms of above-ground carbon storage potential, we identified synergies in the highly dynamic, former lignite mining area in the south of Leipzig in 2000 (restoration began in 1991), but the restoration progress in 2006 converted this positive development into losses and trade-offs with the recreation potential. This result indicates that the tree-covered raster cells from 2000 were converted into green, leisure spaces with less trees or single family home residential areas in 2006, therefore, the above-ground carbon storage potentials declined, but the recreation potential increased. In Figure 8, diagrams f, g and $\mathrm{k}$ are good examples of ecosystem services synergies, and diagrams $\mathrm{a}, \mathrm{e}, \mathrm{h}$ and $\mathrm{j}$ represent weak ecosystem services tradeoffs in the form of loose-no change relations; the remaining diagrams appear to be comparatively indifferent.

Fig. 7. Interactions of five ES for the two time periods of 1990 to 2006, shown in a map format. The displayed interactions should to be read as e.g. the first map shows the results for the ES "Biodiversity potential" as compared to "Food supply".

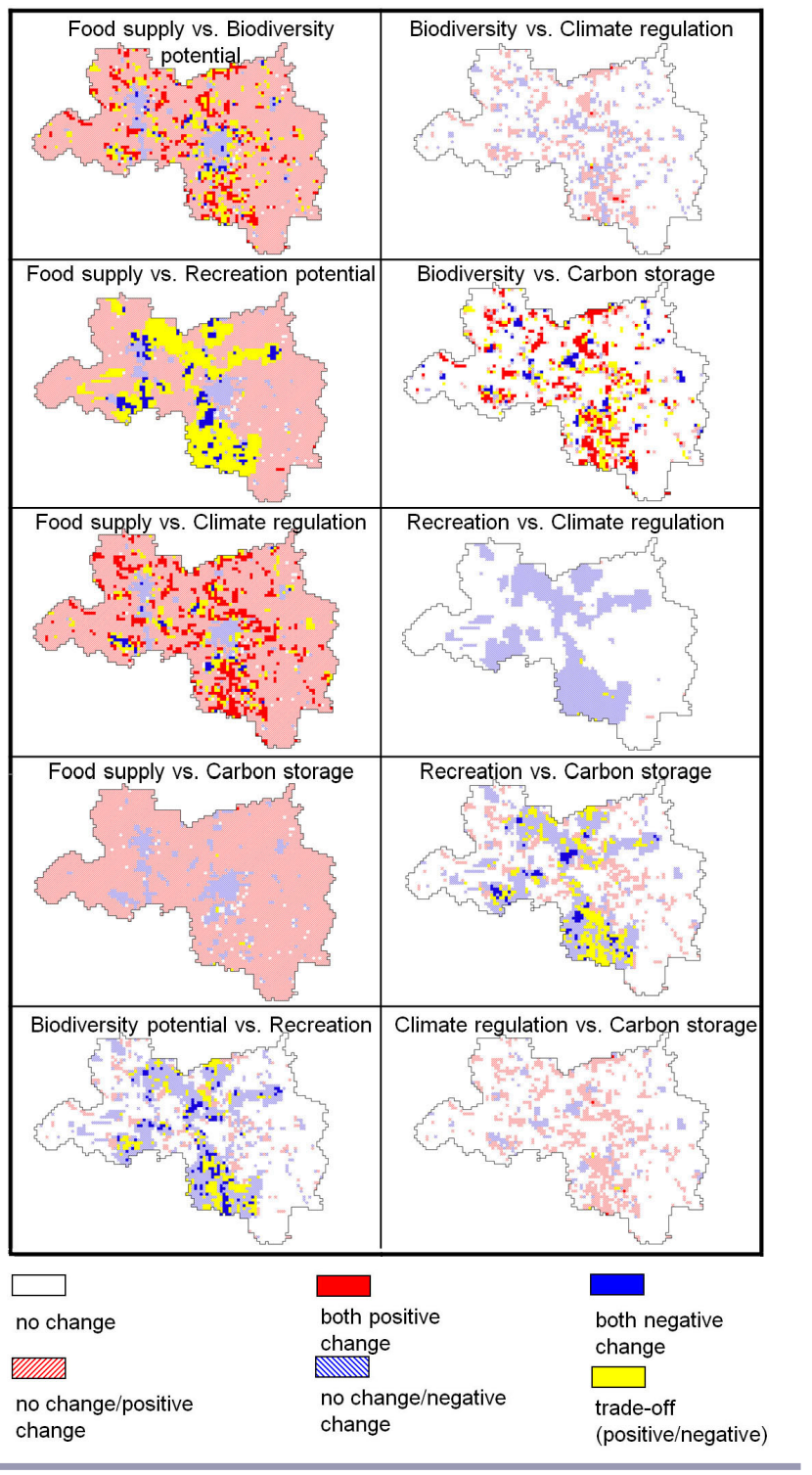


Fig. 8. Accumulated synergies, trade-offs, losses, win-no change, lose-no change and no change interrelations of the pairs of ES (in \%) in the rural-urban region that was driven by land-use change in the time period from 1990 to 2006. Each point represents one $1 \times 1 \mathrm{~km}$ cell.

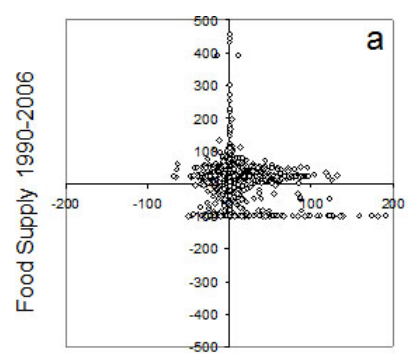

Biodiversity Potential 1990-2006

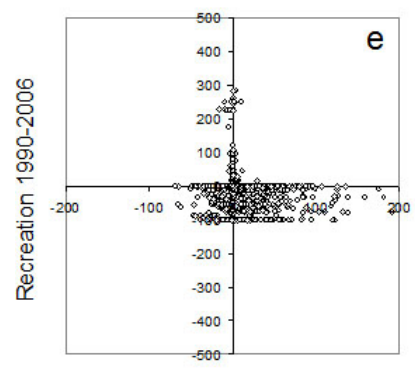

Biodiversity Potential 1990-2006

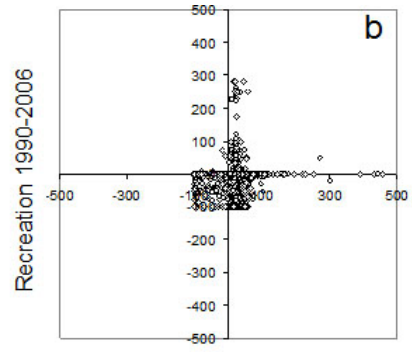

Food Supply 1990-2006

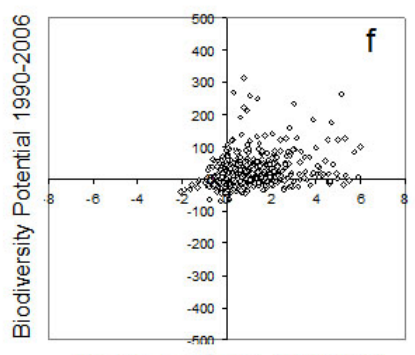

Climate Regulation 1990-2006

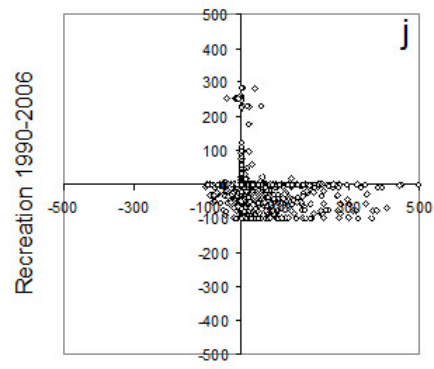

Carbon Storage 1990-2006

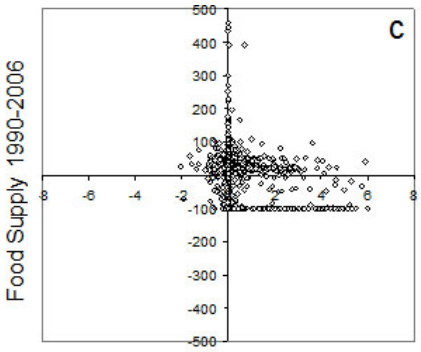

Climate Regulation 1990-2006

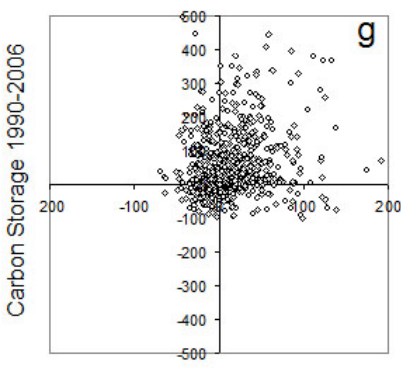

Biodiversity Potential 1990-2006

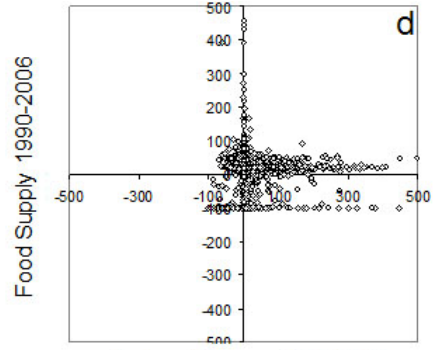

Carbon Storage 1990-2006

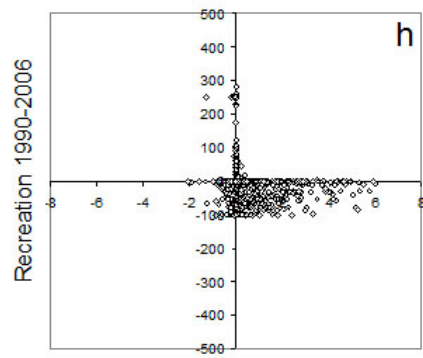

Climate Regulation 1990-2006

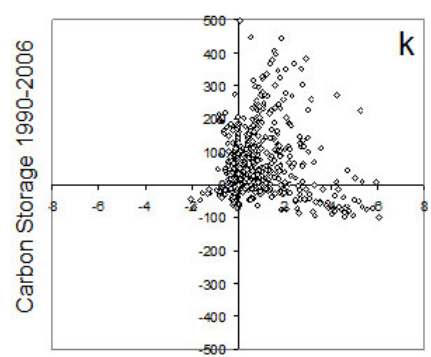

Climate Regulation 1990-2006

Temporal change and delayed potentials of ecosystem services provisioning

Figure 9 shows the results of the analysis of the changes between the bundles of ecosystem services within the time period from 1990 to 2006. Increases in the synergies (9\%), trade-offs $(29 \%)$ or losses $(12 \%)$ of ecosystem services provisions were detected for 1990-2006. Almost no changes were found for the interactions where the local climate regulation was involved because of limited changes in this service over time. The changes that are displayed in Figure 9, which were quantified for a comparatively short period of time but impacted by the remarkable land cover changes, clearly show that the ecosystem services provision assessment is timedependent and that the detection of land-cover change for different points in time can provide a realistic evaluation of what the ecosystems can provide.

\section{DISCUSSION}

Methods used, uncertainties and off-site effects

Uncertainties are unavoidable when performing this type of regional analysis. In our case study, there were two primary sources of uncertainty: land-cover classification errors in the data provided by the EEA and errors from the modeling and quantification of the ecosystem services indicators. The validity of the Corine land cover classification has been confirmed by the European Environment Agency (EEA 2006). The accuracy is approximately $87 \%$ (with 22 out of 44 classes being validated). We work at a regional scale, and thus, an aggregation of land-cover data was necessary. Nevertheless, we captured the main pattern of the data e.g., the degree of imperviousness with the Corine land cover data aggregated at $1 \mathrm{x} 1 \mathrm{~km}$ cell grid. To account for these uncertainties, we only 
Fig. 9. Spatial change of the synergies, trade-offs, and losses when comparing the time period of 1990 to 2000 and the time period of 1990 to 2006 .

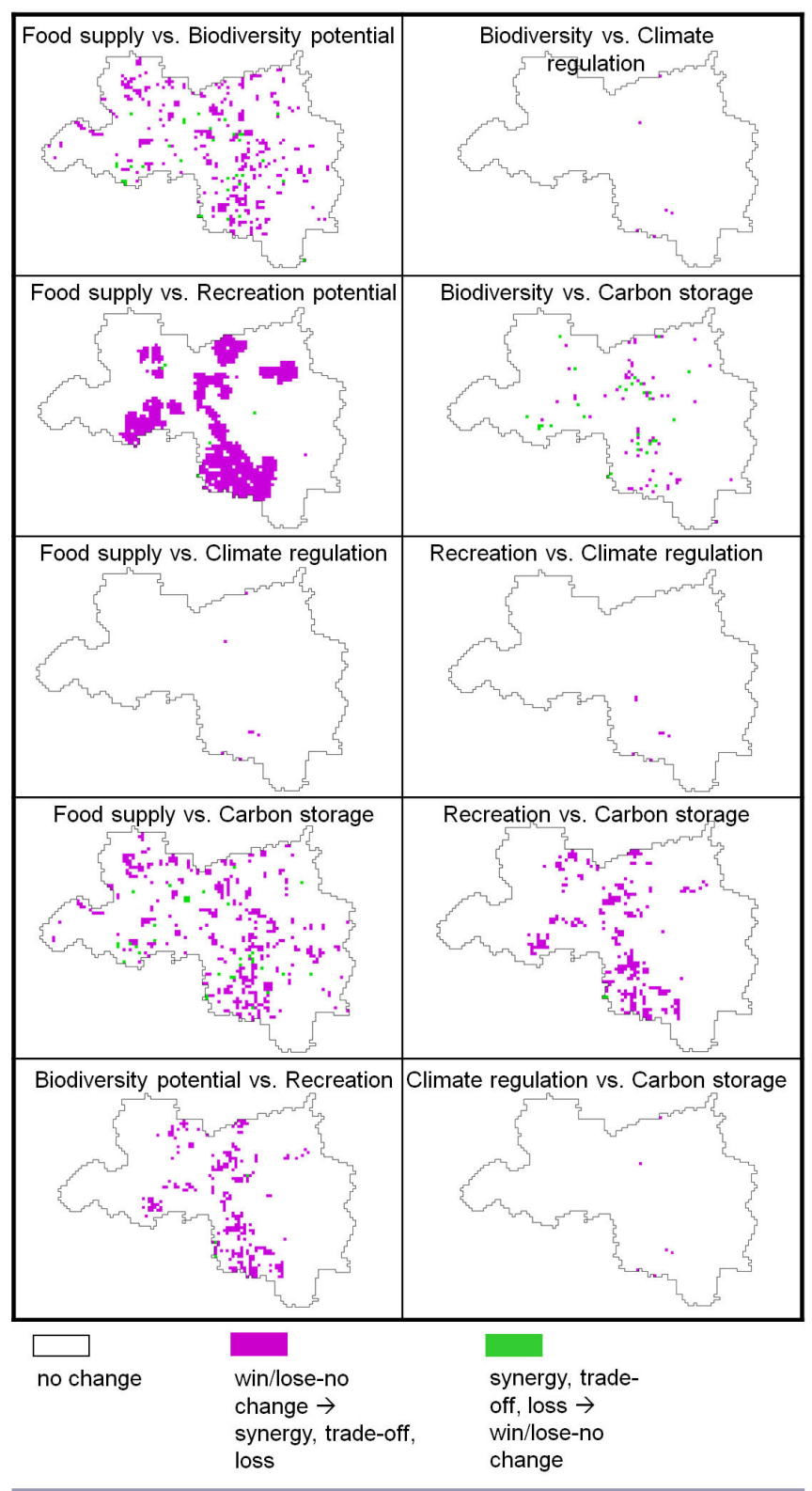

evaluated changes in terms of trade-offs, synergies and losses if the relative change of an indicator was larger than 5\% when compared to 1990. This threshold considers that small changes may be an artifact of the uncertainties. Our analysis used two different time spans, 1990-2000 and 1990-2006; therefore, it indicates and considers uncertainties that are related to the subjective or data-driven choice of the time horizon for such research. Furthermore, we only defined qualitative terms, and we avoided numerical changes in rates to highlight the heuristic nature of our approach. We could show that by using simple models for the five ecosystem services indicators, it is possible to determine the spatial patterns in ecosystem services trade-offs and synergies, as well as their changes, without a large number of uncertainties. Moreover, our framework deals only with trade-offs within a region. Using the food supply service as an example, we interpret the market and subsidiary circumstances of food production as external drivers of the ecosystem services provisions within the region. For this study, we employed statistical data on soil fertility, livestock composition, fruit yields, crop yield, and the composition of cultivated crop types at the administrative district level for the respective years. These data indirectly reflect off-site effects, such as impacts of climatic conditions on crop yields or impacts of food markets and subsidies on the composition of cultivated crop types.

\section{Assessing the analysis framework of the ecosystem services' interactions}

The analysis framework that is presented here regarding the ecosystem services provisioning synergies, trade-offs, and losses provides a clear, additional benefit compared to the existing approaches. Our approach uses different spatial scales and focuses on the interactions between ecosystem services. The results, presented as zoned matrices, spidergrams and maps, are largely consistent across the spatial scales, but aggregation clearly hides the trade-offs and synergies between ecosystem services that appear at a higher spatial resolutions. Both the zone and the cell scale show that the highest loss of ecosystem services occurs over time in the peri-urban areas. On the other hand, the zone-by-zone aggregation ignores the differentiation of synergy, trade-off and loss areas in the urban areas of Leipzig and Halle. Thus, for urban planning, only the grid scale is meaningful.

The analysis framework provides a range of potentials. First and foremost, it is an integrative picture regarding the temporal and spatial development of the ecosystem services and natural resources in an urban region. It also provides an easy identification of synergy, trade-off, losses and no-change relationships among the bundles of ecosystem services at different scales. Therefore, this framework expands the simple trade-off analysis. The indicators that were presented estimate the ES potentials, and they indicate the areas where ecosystem functioning and service provisioning can be improved in an urban region. This is particularly relevant to shrinking and postindustrial cities because, as shown by our results, the range of brownfields in the inner parts of cities may serve recreational purposes. Finally, the analysis framework that was presented here includes an innovative evaluation of the importance of the temporal change of ecosystem services provisioning with respect to land cover change. This framework helped to identify the changes in ecosystem services trade-offs and synergies within short periods of time, and thus, it reinforced the importance of land-cover changes in ecosystem services provisioning. 


\section{Relevance for planning policies}

For policy makers, for example, the overall trends, tendencies or patterns of and between ecosystem services might be more useful than evaluating ecosystem services singularly. All of the different scales were operable using publicly available data, but this does not mean that public bodies working and operating at these scales will be easily introduced to this framework. It is still a scientific concept that needs to be transferred into practice. However, the aggregated indices at the whole case study level and the zone assessment level are suitable for policy analysts and policy-makers because they are easy to artifact, and long-term experience shows that planners and policy analysts are used to working with maps (e.g., Volk et al. 2010). This evaluation is based on the results of a range of stakeholder workshops that were embedded in the EU Integrated Project PLUREL (www.plurel.net; Haase et al. 2010). Ecosystem service trade-offs that were identified here were primarily based on land-cover changes, and therefore, they facilitate the ecosystem services' provisions enhancement and land-cover development and planning by directing land cover in favor of ecosystem services provisioning and nature conservation. This framework can be used as a form of effect/impact analysis on the spatial and land-use strategies on different spatial scales. One example of this is the study regarding the assessment of land cover strategies and their relationship to climate regulation (Schwarz et al. 2011a).

\section{Challenges for implementation}

How does the framework that was presented above contribute to a better implementation of the ecosystem services concept? Research that concerns spatial planning in urban regions has not met the threshold to impact or change policy (Cox and Searle 2009, Colding 2011), but opportunities for this still exist. The reasons for not meeting the threshold for policy impact are manifold. First, there is a lack of information or standards for assessing ES, particularly in the urban regions. Here, empirical evidence is required, and our case study provides precisely this information. Second, Cox and Searle (2009) and Seppelt et al. (2011a, 2011b) noted a lack of scalability. Here, our three-scale framework shows the uncertainties that are related to the different scales in ecosystem services modeling and assessment. Third, the involvement of local stakeholders in ecosystem services modeling and assessment is insufficient (Andersson and Bodin 2009, Borgström et al. 2006). Here, our framework partially contributes to the insufficiency because it provides easy measures that are based on publicly available data, which make the results accessible and comparable. Fourth, land cover is often used as a proxy to quantify the provision of ecosystem services, as in this study. Although the existing systems of land-cover classifications, such as Corine, somewhat simplify the human influence on the landscape (Ellis and Ramankutty 2008), this study shows that the relationships that were observed between the ecosystem services trade-offs and land cover changes can be quantified and made spatially explicit. Fifth, all of the different scales were operable using publicly available data as earlier mentioned. The framework is still a scientific concept that needs to be transferred into practice. Empirical case studies, like the one presented here, help to develop and define standards for ecosystem services' assessments that will make the concept more applicable.

\section{SUMMARY AND CONCLUSIONS}

Our aim was to provide an analytical framework to conceptualize and to quantify interactions between the ES provisioning in an urban region. The framework suggests the use of aggregated values for the entire urban region, functional zones (urban, peri-urban and rural zones) and spatially explicit, raster-transformed maps. It involves an evaluation of the temporal change of an ecosystem services assessment depending on the land cover change. We applied this framework to the urban region of Leipzig-Halle in eastern Germany.

In the case study, on the one hand, the analysis clearly shows a loss in the ecosystem services' provisions as a consequence of soil sealing in the peri-urban areas; on the other hand, it shows the synergies of ecosystem services resulting from brownfield-transition into green space and mining restoration. The study showed that trade-offs and synergies between ecosystem services are not stable relationships and that they might change over short periods of time depending on the change in land cover. At a more general level, the results of the case study showed that the assessment of ecosystem services' provisions succeeds at different scales and delivers consistent results. Because the framework involves a zone-byzone assessment, the growth and shrinkage processes in the urban and peri-urban parts of a region can easily be analyzed. Using the spatial map approach, we can identify and localize areas of change in ecosystem services provisioning synergies and trade-offs. Our framework exclusively addresses the synergies and trade-offs within an urban region and neglects off-site effects, as discussed in section 6. This might lead to an overestimation of the effects of carbon storage, as it is a global service, while underestimating the valuation of recreational spaces that can be accessed from outside the urban regions of study.

The main conclusions of this work are as follows. First, the identification and quantification of the ecosystem services trade-offs and synergy across different scales is operable using simple models. Second, although uncertainties were present, they did not adulterate the results. Third, the different scales of the integrated analysis framework that was presented enables planners and policy-makers to participate in the identification of trade-offs and synergies in their region. The scales used are applicable to different planning hierarchies spanning from the federal (in German: Landesentwicklungsplan) 
to the local planning level (in German: Landschaftsplan, Grünordnungsplan). Finally, the analysis shows the importance of both land-cover and time for the analysis of ecosystem services trade-offs, synergies and losses.

Responses to this article can be read online at: http://www.ecologyandsociety.org/vol17/iss3/art22/ responses/

\section{Acknowledgments:}

We wish to thank our colleagues Felix Müller and Nadja Kabisch for many stimulating discussions. This publication is a result of PLUREL, an Integrated Project under the European Commission's Sixth Framework Programme for research (EC FP6 Contract No. 036921). A portion of the work was kindly supported by the Helmholtz Impulse and Networking Fund through the Helmholtz Interdisciplinary Graduate School for Environmental Research (HIGRADE). Thanks to two anonymous reviewers for their comments and suggestions which helped to improve the quality of the manuscript.

\section{LITERATURE CITED}

Achtziger, R., H. Stickroth, and R. Zieschank. 2004. Nachhaltigkeitsindikatoren für die Artenvielfalt - ein Indikator für den Zustand von Natur und Landschaft in Deutschland, Angewandte Landschaftsökologie 12:111-118.

Amtliche Topographisch-Kartographische Informationssystem (ATKIS). 2006. Topographic Information System of Germany. Landesvermessungsamt Sachsen, Dresden.

Andersson, E., S. Barthel, and K. Ahrné. 2007. Measuring social-ecological dynamics behind the generation of ecosystem services. Ecological Applications 17:1267-1278. http://dx.doi.org/10.1890/06-1116.1

Andersson, E., and O. Bodin. 2009. Practical tool for landscape planning? An empirical investigation of network based models of habitat fragmentation. Ecography 32:123-132. http://dx.do i.org/10.1111/j.1600-0587.2008.05435.x

Baines, C. 2000. How to make a wildlife garden. Second edition. Francis Lincoln. London, UK.

Bastian, O., D. Haase, and K. Grunewald. 2011. Ecosystem properties, potentials and services - the EPPS conceptual framework and an urban application example. Ecological Indicators 21: 7-16. http://dx.doi.org/10.1016/j.ecolind.2011. $\underline{03.014}$

Bennett, E. M., G. D. Peterson, and L. G. Gordon. 2009. Understanding relationships among multiple ecosystem services. Ecology Letters 12:1394-1404. http://dx.doi.org/10 $.1111 / \mathrm{j} .1461-0248.2009 .01387 . \mathrm{x}$
Bolund, P., and S. Hunhammar. 1999. Ecosystem services in urban areas. Ecological Economics 29:293-301. http://dx.doi. org/10.1016/S0921-8009(99)00013-0

Borgström, S. T., T. Elmqvist, P. Angelstam, and C. AlfsenNorodom. 2006. Scale mismatches in management of urban landscapes. Ecology and Society 11(2):16. [online] URL: htt p://www.ecologyandsociety.org/vol11/iss2/art16/

Boyd, J., and S. Banzhaf. 2007. What are ecosystem services? The need for standardized environmental accounting units. Ecological Economics 63: 616-626. http://dx.doi.org/10.1016/ j.ecolecon.2007.01.002

Breuste, J. 2003. Decision making, planning and design for the conservation of indigenous vegetation within urban development. Landscape and Urban Planning 68:439-452. http://dx.doi.org/10.1016/S0169-2046(03)00150-6

Burkhard, B., I. Petrosillo, and R. Costanza. 2010. Ecosystem services - Bridging ecology, economy and social sciences. Ecological Complexity 7:257-259. http://dx.doi.org/10.1016/ j.ecocom.2010.07.001

Churkina, G. 2008. Modeling the carbon cycle of urban systems. Ecological Modelling 216(2):107-113. http://dx.doi. org/10.1016/j.ecolmodel.2008.03.006

Colding, J. 2011. The role of ecosystem services in contemporary urban planning. Pages 228-237 in J. Niemelä, (Editor) Urban Ecology: Patterns, processes and applications. Oxford University Press, Oxford, UK.

Costanza, R., R. d'Arge, R. deGroot, S. Farber, M. Grasso, B. Hannon, K. Limburg, S. Naeem, R. O'Neill, and J. Paruelo. 1997. The value of the world's ecosystem services and natural capital. Nature 387:253-260. http://dx.doi.org/10.1038/387253a0

Cox, S., and B. Searle. 2009. The state of ecosystem services. The Bridgespan Group. [online] URL: http://www.bridgespan. org/state-of-ecosystem-services.aspx? resource=Articles.

Daily, G. C., and P. A. Matson. 2008. Ecosystem services. From theory to implementation. Proceedings of the National Acadamy of Science 28:9455-9456. http://dx.doi.org/10.1073/ pnas.0804960105

Daily, G. 1997. Nature's Services: Societal dependence on natural ecosystems. Island Press, Washington, D.C, U.S.A.

Davies, Z. G., L. E. Jill, A. Heinemeyer, J. R. Leake, and K. J. Gaston. 2011. Mapping an urban ecosystem service: quantifying above-ground carbon storage at a city-wide scale. Journal of Applied Ecology. 49(5):1125-1134. http://dx.doi.o $\mathrm{rg} / 10.1111 / \mathrm{j} .1365-2664.2011 .02021 . \mathrm{x}$

De Groot, R.S. 1992. Functions of Nature: Evaluation of nature in environmental planning, management and decisionmaking. Wolters-Noordhoff, Groningen. DWD (German 
Meteorological Service; Deutscher Wetterdienst) 2010. Climate data survey Germany. Office Wiesbaden.

De Groot, R. S., M. Wilson, and R. Boumans. 2002. A typology for description, classification and valuation of ecosystem functions, goods and services. Environmental Economics 41:393-408.

Egoh, B., B. Reyers, M. Rouget, M. Boded, and D. M. Richardson. 2009. Spatial congruence between biodiversity and ecosystem services in South Africa. Biological Conservation 142:553-562. http://dx.doi.org/10.1016/j.bioco $\underline{\text { n.2008.11.009 }}$

Ellis, E. C., and N. Ramankutty. 2008. Putting people in the map: anthropogenic biomes of the world. Front. Ecol. Environ. 6:439-447. Environmental Agency of Saxony-Anhalt (Editors) 2008. Bodenatlas Sachsen-Anhalt, DVD, Halle.

European Environment Agency (EEA). 2006. The Thematic Accuracy of Corine Land Cover 2000. Assessment using LUCAS (land-use/cover area frame statistical survey), Technical Report No. 7/2006. [online] URL: http://reports.eea. europa.eu/technical_report_2006_7/en/technical_report_7_2006. pdf. 2006 Retrieved 11 25, 2008.

European Environment Agency (EEA). 2007 The Thematic Accuracy of Corine Land Cover 2006. Assessment using LUCAS (land-use/cover area frame statistical survey), Technical Report No. 17/2007. [online] URL: http://www.eea. europa.eu/publications/technical_report_2007_17. Retrieved $1109,2010$.

Food and Agriculture Organization (FAO). 2009. Standard Nutritive Factors Used In Food Balance Sheets. [online] URL: http://www.fao.org/economic/ess/publications-studies/publications/ nutritive-factors/it/ (accessed 08/01/2010).

Fuller, R. A., K. N. Irvine, P. Devine-Wright, P. H. Warren, and K. J. Gaston. 2007. Psychological benefits of greenspace increase with biodiversity. Biology Letters 3(4):390-394. htt p://dx.doi.org/10.1098/rsbl.2007.0149

Guo, Z., L. Zhang, and Y. Li. 2010. Increased dependence of humans on ecosystem services and biodiversity. PLOS ONE 5 (10):1-7. http://dx.doi.org/10.1371/journal.pone.0013113

Haase, D., A. Piorr, N. Schwarz, and I. Zasada. 2010. A new tool for integrated and interactive sustainability impact assessment of urban land-use changes: the PLUREL iIAT. International Environmental Modelling and Software Society (iEMSs). 2010 International Congress on Environmental Modelling and Software Modelling for Environment's Sake, Fifth Biennial Meeting, Ottawa, Canada. David A. Swayne, Wanhong Yang, A. A. Voinov, A. Rizzoli, T. Filatova (Editors.) [online] URL: http://www.iemss.org/iemss2010/index. php?n=Main.Proceedings
Haase, D., and H. Nuissl. 2007. Does urban sprawl drive changes in the water balance and policy? The case of Leipzig (Germany) 1870-2003. Landscape and Urban Planning 80:1-13. http://dx.doi.org/10.1016/j.landurbplan.2006.03.011

Haase, D., and H. Nuissl. 2010. Assessing the impacts of landuse change on transforming regions. Editorial. Land Use Science 5(2): 67-721. http://dx.doi.org/10.1080/1747423X.20 $\underline{10.481074}$

Haines-Young, R. and M. Potschin. 2010. Proposal for a Common International Classification of Ecosystem Goods and Services (CICES) for Integrated Environmental and Economic Accounting, Report to the European Environmental Agency. Department of Economic and Social Affairs Statistics Division, United Nations. ESA/STAT/AC.217 UNCEEA/5/7/ BK.

Hassan, R., R. Scholes, and N. Ash. 2005. Ecosystems and Human Wellbeing: Volume 1: Current State and Trends. Island Press, Washington, D.C., U.S.A. 917 pp.

Hastie, T., R. Tibshirani, and J. Friedman. 2009. The Elements of Statistical Learning: Data Mining, Inference, and Prediction pp. 587-604. Springer.

Holzkämper, A., and R. Seppelt. 2007. Evaluating costeffectiveness of conservation management actions in an agricultural landscape on a regional scale. Biological Conservation, 136:117-127. http://dx.doi.org/10.1016/j.bioco $\underline{\text { n.2006.11.011 }}$

Jansson, Å., and S. Polasky. 2010. Quantifying biodiversity for building resilience for food security in urban landscapes: getting down to business. Ecology and Society 15(3):20. [online] URL: http://www.ecologyandsociety.org/vol15/iss3/ $\underline{\operatorname{art} 20 /}$

Kabisch, N., and D. Haase. 2011. Diversifying European agglomerations: evidence of urban population trends for the 21st century. Population, Space and Place 17:236-253. http: //dx.doi.org/10.1002/psp.600

Kroll, F., D. Haase, F. Müller, and N. Fohrer. 2012. Ruralurban gradient analysis of ecosystem services supply and demand dynamics. Land Use Policy 29(3):521-535. http://dx. doi.org/10.1016/j.landusepol.2011.07.008

Lappé, F.M. 2009. Questions to ask strategies to save our planet. Solutions 1:34-35.

Lautenbach, S., C. Kugel, A. Lausch, and R. Seppelt. 2010. Analysis of historic changes in regional ecosystem service provisioning using land-use data. Ecological Indicators 11:676-687. http://dx.doi.org/10.1016/j.ecolind.2010.09.007

Liaw, A., and M. Wiener. 2002. Classification and Regression by randomForest, $R$ News 2(3):18-22. 
Lorance Rall, E. D., and D. Haase. 2011. Creative Intervention in a Dynamic City: a Sustainability Assessment of an Interim Use Strategy for Brownfields in Leipzig, Germany. Landscape and Urban Planning 100:189-201. http://dx.doi.org/10.1016/ j.landurbplan.2010.12.004

Millennium Ecosystem Assessment (MA). 2005. Ecosystems and human wellbeing: Synthesis. Island Press, Washington, DC.

Ministry for Agriculture and Environment Saxony-Anhalt 2002. Energetische Biomassenutzung in Sachsen-Anhalt, Magdeburg.

Ministry for Agriculture and Environment Saxony-Anhalt 2007. Biomassepotenzialstudie 2007 für das Land SachsenAnhalt, Magdeburg.

Mitchell, R., and F. Popham, 2008. Effect of exposure to natural environment on health inequalities: an observational population study. Lancet 372(9650): 1655-1660. http://dx.doi. org/10.1016/S0140-6736(08)61689-X

Nature. 2010. Wanted: an IPCC for biodiversity. Nature 465 (7298): 525.

Nuissl, H., D. Haase, H. Wittmer, and M. Lanzendorf. 2008. Impact assessment of land-use transition in urban areas - an integrated approach from an environmental perspective. Land Use Policy 26:414-424. http://dx.doi.org/10.1016/j.landusepo 1.2008 .05 .006

Nuissl, H., and D. Rink. 2005. The 'production' of urban sprawl. Urban sprawl in eastern Germany as a phenomenon of post-socialist transformation. Cities 22: 23-134.

Priego, C., J. Breuste, and J. Rojas. 2008. Perception and value of nature in urban landscapes: comparative analysis in cities in Germany, Chile and Spain. Landscape Online 7(1):22. htt p://dx.doi.org/10.3097/LO.200807

Raudsepp-Hearne, C., G. D. Peterson, and E. M. Bennett. 2010. Ecosystem service bundles for analyzing tradeoffs in diverse landscapes. Proceedings of the National Acadamy of Science 107(11):5242-5247. http://dx.doi.org/10.1073/pnas.0 $\underline{907284107}$

Regional Planning Association Western Saxony (RPA Western Saxony). 2008. Regional Plan. [online] URL: http:// www.rpv-westsachsen.de accessed 4 September 2009.

Rink, D. 2009. Wilderness: The Nature of Urban Shrinkage? The Debate on Urban Restructuring and Restoration in Eastern Germany. Nature \& Culture 8(3):275-292. http://dx.doi.org/1 $\underline{0.3167 / \mathrm{nc} .2009 .040304}$

Rodríguez, J. P., T. D. Beard, Jr., E. M. Bennett, G. S. Cumming, S. Cork, J. Agard, A. P. Dobson, and G. D. Peterson. 2006. Trade-offs across space, time, and ecosystem services.
Ecology and Society 11(1):28. [online] URL: http://www.eco logyandsociety.org/vol11/iss1/art28.

Santos, L. D., and I. Martins. 2007. Monitoring urban quality of life: the Porto Experience. Social Indicators Research 80:411-425. http://dx.doi.org/10.1007/s11205-006-0002-2

Saxon Office of Statistics. 2010. Population Statistics, territorial status 31.07.08. [online] URL: www.statistik.sachsen. de accessed 20 July 2010.

Saxony-Anhalt Office of Statistics. 2010. Population Statistics. [online] URL: www.statistik.sachsen-anhalt.de accessed 20 July 2010.

Saxon State Department of Environment and Geology. 2007. Bodenatlas des Freistaates Sachsen, DVD, Dresden.

Saxon State Ministry for the environment and agriculture. 2007. Energie für die Zukunft, Sachsens Potenzial an nachwachsenden Rohstoffen/Biomasse.

Schönbrodt, R., and T. Spretke. 1989. Brutvogelatlas von Halle und Umgebung. Rat der Stadt Halle, Abteilung Umweltschutz und Wasserwirtschaft, Gesellschaft für Natur und Umwelt im Kulturbund der DDR.

Schwarz, N., A. Bauer, and D. Haase. 2011a. Assessing climate impacts of local and regional planning policies Quantification of impacts for Leipzig (Germany). Environmental Impact Assessment Review 31:97-111.

Schwarz, N., S. Lautenbach, and R. Seppelt. 2011b. Exploring indicators for quantifying surface urban heat islands of European cities with MODIS land surface temperatures. Remote Sensing of Environment 115:3175-3186.

Seppelt, R., C. F. Dormann, F. V. Eppink, S. Lautenbach, and S. Schmidt. 2011a. A quantitative review of ecosystem service studies: approaches, shortcomings and the road ahead. Journal of Applied Ecology 48(3):630-636.

Seppelt, R., B. Fath, B. Burkhard, J. L. Fisher, A. GrêtRegamey, S. Lautenbach, P. Pert, S. Hotes, J. Spangenberg, P. H. Verburg, and A.P.E.V. Oudenhoven. 2011b. Form follows function? Proposing a blueprint for ecosystem service assessments based on reviews and case studies. Ecological Indicators. doi:10.1016/j.ecolind.2011.09.003 http://dx.doi.o rg/10.1016/j.ecolind.2011.09.003

Seppelt, R., and A. A. Voinov. 2003. Optimization methodology for land use patterns-evaluation based on multiscale habitat pattern comparison. Ecological Modelling, 168:217-231.

State Environmental Agency (STUFA). 1995. Brutvogelatlas der Stadt und des Landkreises Leipzig. Materialien zu Naturschutz und Landschaftspflege, Freistaat Sachsen. 
Steffan-Dewenter, I. 2007. Tradeoffs between income, biodiversity, and ecosystem functioning during tropical rainforest conversion and agroforestry intensification. Proceedings of the National Acadamy of Science 104 (12):4973-4978. http://dx.doi.org/10.1073/pnas.0608409104

Stewart, I. D. 2011. A systematic review and scientific critique of methodology in modern urban heat island literature. International Journal of Climatology, 31(2):200-217. http://d x.doi.org/10.1002/joc. 2141

Strohbach, M., and D. Haase. 2012. The above-ground carbon stock of a central European city: patterns of carbon storage in trees in Leipzig, Germany. Landscape and Urban Planning 104:95-104.

Strohbach, M. W., D. Haase, and N. Kabisch. 2009. Birds and the city: urban biodiversity, land use, and socioeconomics. Ecology and Society 14(2):31. [online] URL: http://www.eco logyandsociety.org/vol14/iss2/art31/.

Tratalos, J., R. A. Fuller, P. H. Warren, R. G. Davies, and K. J. Gaston. 2007. Urban form, biodiversity potential and ecosystem services. Landscape Urban Plan 83: 308-317. htt p://dx.doi.org/10.1016/j.landurbplan.2007.05.003

Troyer, M. E. 2002. A spatial approach for integrating and analysing indicators of ecological and human condition. Ecological Indicators 2: 211-220. http://dx.doi.org/10.1016/S 1470-160X(02)00044-4

United Nations, Department of Economic and Social Affairs, Population Division. 2008. World urbanization prospects: The 2007 revision. [online] URL: http://esa.un.org/unup [accessed 2 July 2009].

Volk, M., S. Lautenbach, H. van Delden, L. T . H. Newham, and R. Seppelt. 2010. How can we make progress with decision support systems in landscape and river basin management? Lessons learned from a comparative analysis of four different decision support systems. Environmental Management 46 (6):834-49. doi:10.1007/s00267-009-9417-2. http://dx.doi.org /10.1007/s00267-009-9417-2

Webster, A. J. F. 1980. The Energetic Efficiency of growth. Livestock Production Science 7(5):243-252.

Wenk, C., H. P. Pfirter, and H. Bickel. 1980. Energetic aspects of feed conversion in growing pigs. Livestock Production Science 7(5):483-495. http://dx.doi.org/10.1016/0301-6226(80) 90086-X

Whitford, V., A. R. Ennos, and J. F. Handley. 2001. City form and natural process - indicators for the ecological performance of urban areas and their application to Merseyside, UK. Landscape Urban Plan 57:91-103. http://dx.doi.org/10.1016/ S0169-2046(01)00192-X
Yli-Pelkonen, V., and J. Nielema. 2005. Linking ecological and social systems in cities: urban planning in Finland as a case. Biodiversity and Conservation 14:1947-1967. http://dx. doi.org/10.1007/s10531-004-2124-7 


\section{Appendix 1.}

Table A1.1. Models used to quantify the ES indicators.

\begin{tabular}{|c|c|c|}
\hline $\begin{array}{l}\text { Ecosystem } \\
\text { service }\end{array}$ & $\begin{array}{l}\text { Indicator } \\
\text { and Unit }\end{array}$ & Model description \\
\hline $\begin{array}{l}\text { Local } \\
\text { climate } \\
\text { regulation }\end{array}$ & $\begin{array}{l}\text { Surface } \\
\text { emissions } \\
\text { [index] }\end{array}$ & $\begin{array}{l}\text { A lookup-table was built to link the land cover classes to the } \\
\text { land surface emissions. The relationship was estimated by } \\
\text { combining the Corine land cover data for the year } 2000 \text { and the } \\
\text { Landsat } 7 \text { ETM+ thermal band } 6.1 \text { (image courtesy of the U.S. } \\
\text { Geological Survey; spatial resolution } 60 \mathrm{~m} \text { x } 60 \mathrm{~m} \text { ). The satellite } \\
\text { scene was collected on } 20 \text { August } 2002 \text { at approximately } 10: 30 \\
\text { am. The following index was created for each land cover i to } \\
\text { show the differences in the thermal emissions: } \\
\text { emissionIndex [i]=emission [i] / emission [forest] } 100-100 \\
\text { The indices for the land cover classes were created without } \\
\text { correcting for in-scene variability or atmospheric influence. } \\
\text { More details can be found elsewhere (Schwarz et al., 2011a). }\end{array}$ \\
\hline $\begin{array}{l}\text { Recreation } \\
\text { potential }\end{array}$ & $\begin{array}{l}\text { Green space } \\
\text { per capita } \\
{\left[\mathrm{m}^{2} /\right.} \\
\text { person] }\end{array}$ & 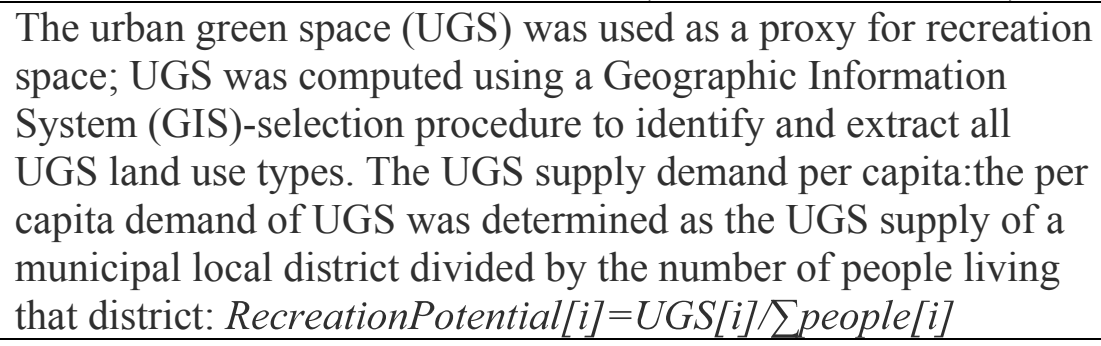 \\
\hline $\begin{array}{l}\text { Carbon } \\
\text { mitigation }\end{array}$ & $\begin{array}{l}\text { Above } \\
\text { ground } \\
\text { carbon } \\
\text { storage } \\
{\left[\mathrm{MgCO}_{2}\right]}\end{array}$ & $\begin{array}{l}\text { Above-ground carbon was estimated based on field data } \\
\text { collected for the Leipzig region (Strohbach und Haase, 2012). } \\
\text { Trees were sampled in } 190 \text { plots stratified over } 19 \text { land-cover } \\
\text { classes ( } 10 \text { plots per land-cover classes) and above ground } \\
\text { biomass was estimated with allometric equations. The carbon } \\
\text { content of the trees is roughly } 50 \% \text { of the biomass. For } \\
\text { transferring the above-ground carbon values to the CORINE } \\
\text { land cover, we first intersected the two land cover layers in a } \\
\text { GIS. Then we calculated the new storage values for the CORINE } \\
\text { land cover classes as the area weighted averages of the values } \\
\text { from Strohbach and Haase (2012) that fell into them. The } \\
\text { resulting carbon storage values are shown in table S3. }\end{array}$ \\
\hline $\begin{array}{l}\text { Biodiversity } \\
\text { potential }\end{array}$ & $\begin{array}{l}\text { Habitat } \\
\text { potential for } \\
\text { bird species } \\
\text { [index] }\end{array}$ & $\begin{array}{l}\text { Breeding bird species that indicated diverse agricultural and } \\
\text { forest habitat types listed in Achtziger et al. (2004) and shown in } \\
\text { table S3 were selected from existing surveys from Leipzig and } \\
\text { Halle (Saale) (Schönbrodt \& Spretke, 1989; STUFA, 1995). } \\
\text { Habitat models were developed for each species. The models } \\
\text { built on the statistical relationship between environmental data, } \\
\text { the land cover and the presence or absence of the indicator } \\
\text { species. RandomForest machine learning algorithms (Liaw and } \\
\text { Wiener, 2002) were used to predict the probability of a certain } \\
\text { cell to be inhabited by a bird species. By combining the results } \\
\text { from several species, the biodiversity potential for } 1990 \text { was } \\
\text { estimated as a value between } 0 \text { (no potential) and } 1 \text { (high } \\
\text { potential). The habitat models were then applied to the whole }\end{array}$ \\
\hline
\end{tabular}


region and to the 2000 and 2006 land cover.

Food Food Regression models see below

supply supply

[GJ/ha] 
Table A1.2. Pearson's correlation coefficients (r) between the crop yield and soil fertility of different crops in 1991, 2000, 2007 with $n=24$ districts of Saxony and Saxony-Anhalt.

\begin{tabular}{|c|c|c|c|c|c|c|c|c|c|c|}
\hline \multirow{5}{*}{$\begin{array}{l}\text { Soil } \\
\text { fertility } \\
\text { index }\end{array}$} & \multicolumn{10}{|c|}{ Yield } \\
\hline & $\stackrel{\bar{\varpi}}{\grave{\nu}}$ & 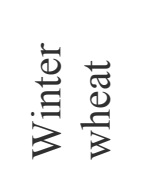 & 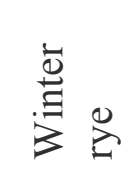 & 离总 & $\tilde{0}$ & 葋 & \begin{tabular}{l}
$\mathscr{E}$ \\
0 \\
0 \\
\multirow{0}{0}{} \\
0
\end{tabular} & 总 & 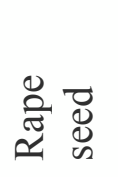 & 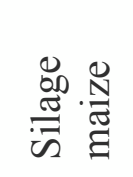 \\
\hline & 1991 & $0.52 * *$ & 0.22 & $0.52 * *$ & $0.47 * *$ & 0.31 & 0.12 & 0.3 & 0.29 & 0.03 \\
\hline & 2000 & $0.58 * *$ & $0.64 * *$ & $0.76^{* *}$ & 0.29 & $0.48 * *$ & 0.25 & 0.16 & 0.09 & 0.23 \\
\hline & 2007 & $0.57 * *$ & $0.33 *$ & $0.51 * *$ & 0.03 & $0.44^{*}$ & 0.14 & 0.29 & 0.03 & $0.61 * *$ \\
\hline
\end{tabular}


Table A1.3. Above-ground carbon storage in trees for the CORINE land cover classes. Values were transferred from Strohbach and Haase (2012). Numbers in brackets are standard errors based on sampling and usage of allometric equations but not on uncertainties from transferring the original values to CORINE land cover.

\begin{tabular}{ll}
\hline CORINE land cover class & $\begin{array}{l}\text { Above-ground carbon storage } \\
{\left[\mathrm{Mg} \mathrm{C} \mathrm{ha}^{-1}\right]}\end{array}$ \\
\hline Continuous urban fabric (111) & $9.66( \pm 5.04)$ \\
Discontinuous urban fabric (112) & $12.83( \pm 4.52)$ \\
Industrial or commercial units (121) & $7.5( \pm 4.39)$ \\
Road, rail networks and associated land (122) & $2.23( \pm 1.25)$ \\
Airports (124) & $0.9( \pm 0.16)$ \\
Mineral extraction sites (131) & $2.99( \pm 0.91)$ \\
Dump sites (132) & $7.36( \pm 1.54)$ \\
Construction sites (133) & $4.66( \pm 0.67)$ \\
Green urban areas (141) & $29.67( \pm 5.25)$ \\
Sport and leisure facilities (142) & $12.59( \pm 3.46)$ \\
Non-irrigated arable land (211) & $2.2( \pm 0.46)$ \\
Fruit trees and berry plantations (222) & $4.01( \pm 1.25)$ \\
Pastures (231) & $5.73( \pm 0.95)$ \\
Complex cultivation patterns (242) & $7.36( \pm 1.5)$ \\
Deciduous forest (311) & $62.21( \pm 9.09)$ \\
Coniferous forest (312) & $58.18( \pm 5.64)$ \\
Mixed forest (313) & $63.54( \pm 7.56)$ \\
\hline
\end{tabular}


Table A1.4. Indicator species for agricultural land and forests from Achtziger et al. (2004) used as basis for calculating the habitat potential.

\begin{tabular}{ll}
\hline \multicolumn{1}{c}{$\begin{array}{c}\text { Biodiversity indicator species from Achtziger et al. (2004) } \\
\text { agricultural land }\end{array}$} & \multicolumn{1}{c}{ forests } \\
\hline Alauda arvensis (Skylark) & $\begin{array}{l}\text { Dendrocopos medius (Middle Spotted } \\
\text { Woodpecker) }\end{array}$ \\
Emberiza citrinella (Yellowhammer) & $\begin{array}{l}\text { Dendrocopos minor (Lesser Spotted } \\
\text { Woodpecker) }\end{array}$ \\
Lanius collurio (Red-backed Shrike) & Dryocopus martius (Black Woodpecker) \\
Miliaria calandra (Corn Bunting) & Sitta europaea (Eurasian Nuthatch) \\
Milvus milvus (Red Kite) & Phylloscopus sibilatrix (Wood Warbler) \\
Vanellus vanellus (Northern Lapwing) & \\
\hline
\end{tabular}

